\title{
DETERMINATION OF THE ECONOMIC GROWTH RATES BY THE GROWTH QUALITY
}

\author{
Nada Trivic*, Viktorija Petrov \\ Faculty of Economics in Subotica, University of Novi Sad, Subotica, Serbia
}

Each specific economic growth rate indicates relevant characteristics of current development, but also reflects the chances for achieving satisfactory future growth rate. Therefore, it is about a general interdependence and law of growth rate convergence. The main objective of this paper is to show that substandard growth could, sooner or later, result in the economic slowdown, and that the temporary growth acceleration can be achieved at the expense of the long-term growth rate. Scientific instruments applicable for achieving this research goal are the method of scientific analysis, historical method and the method of comparative analysis, as well as a number of techniques in the form of modern information resources. A key result of this paper is that all growth rates of endogenous production factors, without increasing the efficiency of resource use, are converging to the arithmetic mean of exogenous production factors growth rates. Therefore, the growth rate can be significantly increased at the expense of its quality and the substandard growth contains the "germs of its own limiting".

Keywords: growth rate, convergence, efficiency, growth quality, growth rates interdependence

JEL Classification: C10, D63, 047

\section{INTRODUCTION}

The view of economic development as an extremely complex and multidimensional phenomenon seems standard and somewhat trivial. Attempts to measure it face major conceptual and methodological difficulties and differences in application and interpretation (Average Annual Growth Rate: www.investinganswers. com). Some aspects of the development are completely immeasurable, others are partially measurable, whereas some of them allow so much freedom and

\footnotetext{
* Correspodence to: N. Trivic, Faculty of Economics in Subotica, University of Novi Sad, Segedinski put 9, 24000 Subotica, Serbia; e-mail: ntrivic@ef.uns.ac.rs
}

arbitrariness that in some cases they would be better if left unmeasured. Certainly, an important element of economic development is economic growth. Economic growth means the growth of production, production capacities, and all other segments of an economy. Economic growth is an increase in the total output of an economy. The pace of economic growth is mainly measured and expressed by a growth rate. However, growth rates, as development indicators, contain a number of limitations:

- they are calculated on the basis of initial data of a varying quality and authenticity;

- they are sensitive to the range and depth of structural changes; 
- statistics offer plenty of opportunities for the manipulation and modification of officially presented data, based on which growth rates are calculated;

- empirical results point to a link between the level and pace of growth, so that growth rates are not comparable when considering countries with different levels of development;

- different technological solutions and the experience of some countries make growth rates incomparable;

- some countries may have relatively high growth rates, which points to the fact that development reserves are depleted;

- growth rates, as figures, do not point to the quality of growth, so that quality, as an enormous, but immeasurable area, remains in the shadow, although it stands for an important aspect, as much as quantity does.

The main objective of this paper is to show that extensive growth (based on labour and natural resources) contains germs of its own limitation, reflected in the depletion of exogenous sources of growth. Therefore, the quality of growth must also be taken into consideration (Denison, Jorgenson \& Grilichers, 1972, 157). An analysis of the quality of growth is particularly important in conditions of a rapid economic expansion, when favourable conclusions are easily drawn. However, a high rate of growth is not a guarantee of its quality. The second objective of this analysis is to show that substandard growth is expressed as a limiting factor to the growth of production in the future, because of the temporal interdependence of growth rates. Nevertheless, if an economy achieves rapid growth in the long run, there are grounds for assuming that such growth is of a high quality (Mawson, 2002, 432). In addition, an analysis of economic growth is long-term by nature, so that in the course of analyses of shorter periods, the temporal interdependence of growth rates must be taken into account.

Based on the methodology of calculating growth rates and the above limitations, two hypotheses can be established:
H1: Growth rates observed in different periods are temporally interdependent, and determined by the quality of growth;

$\mathrm{H} 2$ : In conditions of extensive growth, there is convergence of growth rates.

The hypotheses, seemingly indisputable, become quite acceptable when taking into consideration explanations based on economic theory and some practical results. Moreover, the hypotheses raise a number of issues relevant to the institutional solutions and economic policy measures of virtually every economy, and in some areas they have become part of the fundamental economic knowledge. Since the defined hypotheses have a theoretical and methodological character, this study relies on a number of scientific methods. However, the subject of the research predominantly focuses on the application of the methods of a scientific analysis, the historical methods, and the methods of a comparative analysis, as well as a number of techniques in the form of modern information resources.

The defined hypotheses make up the structure of this work in accordance with the basic objectives: the first part indicates the temporal interdependence of growth rates, whereas the second part points to the convergence of growth rates. Both parts of the analysis point to the conclusion on the importance of efficiency, which stands for a key economic problem.

\section{TEMPORAL INTERDEPENDENCE OF GROWTH RATES}

The efficiency of economic development is mainly viewed through levels and changes in the pace of growth. However, if an analysis includes changes in the pace of growth, in addition to the level of growth, the overall process is relativized and the resulting scores are ambiguous. It means that the same growth rate can differently be assessed, depending on whether it is preceded by high or low growth rates. It should be noted that any specifically observed rate reflects the relevant characteristics of the current development, but also affects the development conditions and chances of achieving a satisfactory growth rate in the future. 
The extent to which a given growth rate is seen as successful depends on the complex overall configuration of growth rates recorded in the previous period. In addition, the output of one period is assessed not only on the basis of the immediate results registered within this period, but also on the basis of the dynamic potential to be transferred to the next period (Growth Rates and Terminal Value: www.stern. nyu.edu/.../growthandtermvalue.pdf). Therefore, it is necessary to assess it on the basis of the extent to which it has prepared the ground for the realisation of favourable future growth rates.

In a specific period, a set of institutional solutions can generate good results, while containing (as a tendency or ability) elements that may reduce future growth rates (Denison \& Poullier, 1967, 132-137). Such a set of institutional solutions enables the achievement of high growth rates, but also has a potential to create new solutions that will significantly reduce future rates. At some period, a rapid growth can be forced, while inevitably and drastically reducing development opportunities in the forthcoming period, or even preventing any development. The situation is reversed if the current period inherits favourable development opportunities from the previous period (Denison, 1984, 82). Then, the growth rate from the previous period, if taken as an indicator of success, must be reduced by as much as the development process reduced the chances of achieving a satisfactory rate in the current period. The same logic applies to the future. This interdependence is particularly characteristic of economies characterised by periods of low growth rates, economic stagnation, and a period of relatively (or especially) high growth rates (Komazec i Ristić, 2011, 133).

It often happens that a development policy must for some time turn to difficult, painful and laborious structural and other modifications. To the extent that low growth rates, resulting from such a modification, really set the stage for a successful future development, such growth rates can, despite a moderate level, be interpreted as a significant result of the economic policy. Therefore, the successful development of one period is not independent of the development trends and performance in the past and in the future. It is the "phenomenon of the temporal interdependence of the growth rates achieved in the successive intervals of the observed period" (Madžar, 1981, 38). Due to general interdependence, each specifically observed growth rate reflects the relevant characteristics of the development processes in the past, and affects the conditions of development and a pace of growth in the future. Low growth rates recorded in some period, among other things, may be the result of high indebtedness, whereas relatively high growth rates recorded in previous periods would be lower if they did not increase at the expense of the current (low) rates.

It is possible to imagine the development process in which growth rates are the sole result of the measures and steps taken in that period only as an ideal and hypothetical model, but under highly restrictive assumptions. In that case, under highly unrealistic assumptions, growth indicators would be obtained in a form of growth rates, which would be interpreted as indicators of the development in the observed period, regardless of the period preceding and following it. In reality, there are no such cases, especially not in the economies exposed to a number of exogenous shocks, sudden and numerous political reversals, and an arduous process of institution building.

The mechanism of the temporal interdependence of growth rates is very complex, and acts through specific (sometimes independent) loops of macroeconomic aggregates. The following can be determined as the basic mechanisms:

- foreign debt,

- import dependence,

- change in the structure of investments,

- erosion of capital in inflationary conditions,

- costs of exploitation of natural resources and depletion of stocks, and

- interdependence of institutional solutions.

\section{Foreign debt}

In a certain period, investments can rapidly increase if the economic policy is focused on the strategy of intensive borrowing. In view of the growth of 
production, growth rates would increase, but this is not a sign of a successful economic policy. That growth of production is a result of the resources coming from other economies. When the inflow of foreign funds is exhausted, and there is a phase of debt repayment, the investment potential of the economy decreases rapidly, and growth deceleration occurs, as a result of the contrived and foreign funded (previous) acceleration or the reduction of a future development potential (Relative Rates of Growth: www.math.psu.edu/ files/141rates1.pdf.

If, in addition, the borrowed funds are badly used, it further reduces the overall effects. To illustrate these effects, neither the model nor imagination is needed, but rather an insight into what is happening in our economy (The Statistical Office of the Republic of Serbia, 2013, Current Growth Indicators). The conclusion is that a low growth rate is affected by excessive indebtedness, and that growth rates in some prior periods could have been far below if they had not increased at the expense of the current, low rates.

\section{Import dependence}

Empirical data show that some economies have been highly dependent on import for decades. In such conditions, the volume of production and the growth rate significantly depend on the level of import. In that case, the acceleration of growth is achieved due to the improvement of the supply of imported goods, which is provided by the depletion of foreign exchange reserves. It usually happens that a decrease in foreign exchange reserves coincides with an increase in inventories of imported raw materials. However, such a depletion of foreign exchange reserves creates assumptions for an inevitable slowdown in the pace of growth in the future. A possible revival of growth dynamics in such circumstances has to wait for the renewal of reserves.

\section{Change in the structure of investments}

Various investment projects have different sets of actual and expected results. Some projects produce results in the current year, while the majority of others have small effects in the current year, with larger positive effects in a three-year or five-year period. It is clear that a number of different sets of projects can occur in any given period, with the same volume of investments, resulting in a different growth of production, which implies different growth rates in different periods.

In order to illustrate the idea of the temporal interdependence of growth rates, all investment projects can be classified into two groups: the first group includes projects that generate most of its results in the current year and years around the current year; the second group includes projects whose maximum effects are achieved over a relatively long period of time. It is clear that many different combinations of projects with a different volume of investments and different results are possible, and in certain periods, different combinations of projects with the same volume of investments provide significantly different results (Gligorić, 2013, 112). Results can range from practical stagnation to a sudden increase in production in the same or different time intervals. It will, of course, affect the growth rate in other periods, more or less remote from the observed period.

A special form of temporal interdependence in the pace of growth are the differences in the activation periods of individual projects, as well as a varying number of unfinished projects continuing from one period to another. If there is a great mass of unfinished projects that the given period inherits from the previous one, and if the distribution of the time of the completion and the time of the generation of results is favourable, it is likely that high growth rates will be achieved in the observed period. However, such growth rates are not the result of the efforts and policies of the given period, but rather a kind of inheritance or a gift, carried forward from the past. Nevertheless, a reverse situation is possible as well: investments in the current period and an increase in the mass of unfinished projects, in order to increase a future growth potential. In that case, the current growth rate will be reduced to some extent, but the measures and steps taken will be valorised in the future through higher growth rates in the period to come.

In addition, some investments do not provide high current effects. Moreover, in respect of investments in the infrastructure, there are no direct effects at all. 
These investments, however, generate a multitude of indirect effects in the long run, particularly by increasing possibilities for doing more efficient business (cheaper and faster transportation, better communication, developed and reliable information systems...). Moreover, they reduce the cost of a wide range of economic activities as well as the economy as a whole. When these investments result in "savings", future operating costs are much higher than they could reasonably be expected, and the economy, through increased running costs, pays a high interest on the funds "borrowed" from the infrastructure activities and invested in direct production activities with fast and short-term effects. In addition, the costs of the inefficient functioning of the system are always high, but largely invisible and immeasurable in operational terms. They exhaust the economy and the population, and thus reduce the economic potential, practically reducing the available funds and preventing the effective use of the decreased investment potential.

\section{Erosion of capital in inflationary conditions}

The erosion of capital in inflationary conditions is an interesting mechanism of the interdependence of the pace of growth. As practice unequivocally shows, an invisible erosion of capital occurs in inflationary conditions, non-observed in terms of accounting.

In inflationary conditions, the reported domestic product is overrated because an invisible decrease in social capital is expressed as a supplement to the domestic product (Komazec i Ristić, 2009, 118). This is how growth rates are deformed. For example, the calculation of depreciation, which does not allow for the maintenance of the net value of capital, contributes to the overrated value added at the expense of social wealth. An underrated price index contributes to an overrated quantity index, and thus, ultimately, to an overrated growth rate.

The erosion of working capital is very characteristic. Under inflationary conditions, the logic of the calculation and maintenance of the nominal value directly results in the insufficiency of the same or greater financial resources for the reconstruction of real working capital, required for the smooth flow of reproduction.

\section{Costs of exploitation of natural resources and depletion of stocks}

It is a well-known fact that natural resources are virtually not measured and expressed through the existing system of accounting. The reported domestic product does not reflect the quantity of irreversibly consumed non-renewable resources. Over time, for example, certain ore deposits are depleted, while less accessible and expensive deposits are exploited, which reduces the domestic product and the pace of its growth. This especially applies to the quality of investment goods, where cost savings, achieved at the expense of quality (in a negative sense), are several times compensated by higher operating costs. Poor quality raw materials and production materials also mean higher costs, as production is more difficult, delays in production are more frequent and longer, and there are possible technological complications. At the same time, the previously reported gross domestic product and the pace of its growth would obviously be overrated because of ignoring the cost of the exploitation of scarce resources. Of course, these deviations are entered in the calculation of growth rates.

The impact of this mechanism on the growth rate could be eliminated if there were a bookkeeping way to determine the costs of non-renewable natural resources and to reduce the calculated added value by their amount.

Furthermore, if deposits discovered in the past are used, without investing in the discovery of new deposits, investments are reduced and realised effects are obtained at the cost of reducing a development potential in the future, when the economy finds itself in a situation that it cannot replace depleted deposits. This means that the allocation of investment funds in exploration and exploitation directly affects the choice of the time profile of the growth rate in certain periods (Hansen \& Hodrick, 1980, 829-853).

For an analysis of short-term fluctuations in growth rates, the level of capacity exploitation is relevant 
as well. When production is at its full speed, in the upward phase of the cycle, an increase in the degree of capacity exploitation is evident. However, such an increase cannot be extended indefinitely if reserves become depleted. The same effect occurs in the case of the depletion of stocks.

\section{Interdependence of institutional solutions}

The development performance of an economy in different periods is interrelated. Links between them are established through institutional changes, and the way in which one set of institutional solutions derives from another, previous set. Interactions between individual institutional solutions are very complex and not suitable for an accurate analysis, so that their strict propositions cannot be identified (Petrović, Bajec, Živković, Arandarenko, Arsić, i drugi, 2010, 98). However, their existence and the significant consequences of their actions are verified.

The principle that stands for the basis of institutional interdependence is very simple. A particular set of institutional solutions can in a given time period be very functional and generate very good results. However, it can contain in itself (as a possibility or tendency) the elements of new solutions that, once enshrined in the regulatory system, can significantly reduce development performance, even the performance expressed through the growth rate. The topicality of this issue is further increased by the fact that, in a given period, some economies reached growth rates that were (at the time) among the highest in the world, which economies, in recent decades, have faced stagnation and a crisis of growth (Rikalović, 2010, 128). Growth faces a slowdown, growth rates at times enter the zone of negative values and the qualitative indicators of development processes show an increasing inferiority compared to developed economies.

The questions which ought to be answered are: How could it happen that essentially the same systems were successful in certain periods and then very unsuccessful? Is it possible that almost the same institutional mechanism shows high efficiency in one and a very poor performance in another period? How much can a set of institutional solutions and instruments be regarded as successful if it enables the achievement of high growth rates and also has a potential or a tendency to produce solutions that inevitably lead to a future reduction in the growth rate? Institutional interdependence, as the basis for successful development in a given period, can condemn future development efforts to failure.

The system learns within time and over time (Madžar, 1990, 153). The process of adaptation to new institutional conditions also requires time and involves a sufficiently long transitional regime, within which regime efficiency falls far below the usual and standard levels. In fact, in this case, there appears to be one additional mechanism of the temporal interdependence of growth rates: delayed changes prevent disruptions and the slowdown of growth, but the system as a whole becomes more ossified and sinks more into the current institutional framework. Practically, delayed changes close a long-term perspective of development. It is yet another mechanism by which the longterm growth rate is sacrificed in order to preserve its relatively high level in the short term (Publishing OECD, 2012, 326). Partial and/or incomplete changes leave room for future disruptions and new iterations of institutional adjustment. Serious changes are only approached when they become unavoidable and urgent, and as such, they do not reach the final causes - they rather remain on the surface, at the level of the perceived problems. Material trends are the result of institutional mechanisms, so that institutional determinants have a character of the fundamental and, for economists, final causes, whereas material factors have a character of derived factors. In addition, the institutional framework can only be evaluated by the results generated by the economic system as a whole, and the institutional framework is only one of the determinants of the total economic output, so that it is almost impossible to distinguish the contribution of the system from the contribution of other determinants.

Therefore, there is a number of resources and reserves of growth that can be depleted in a given period, at the expense of the future (Chan, Karceski, \& Lakonishok, 2002, 108). Therefore, it can be concluded that the perception of growth rates (as development indicators) depends on the general constellation of developmental performance, especially on the rates achieved 
immediately after the observed period, which proves Hypothesis H1. The perception of growth rate (and other indicators to which the same arguments apply) depends on the general constellation of developmental performance, especially on the rates achieved before and immediately after the observed period. It is obvious that among growth rates at different times there is a very complex, subtle, but realistic and influential relationship of interdependence, which makes it inappropriate to treat any growth rate in isolation. It also means that development processes require an integrated approach and a comprehensive analysis.

Therefore, the success of economic growth in any period cannot be measured by the growth rate reached only during this period, given the temporal interdependence of growth rates. Growth rates and other development indicators achieved in a period should be very carefully treated and with a lot of qualifiers, as a result of development and institutional efforts from the observed period. Because of the temporal interdependence of growth rates, each of them has deep roots not only in the immediate but in a distant past as well (Definition of 'Economic Growth Rate': www.investopedia.com/.../Economicgrowthrate. as...).

\section{CONVERGENCE OF GROWTH RATES}

The past practice has shown that extensive growth contains mechanisms for own limitation, which are based on the depletion of the exogenous sources of growth (Madžar, 1990, 307). Once these resources are depleted, growth faces a slowdown, with a tendency towards economic stagnation. Extensive growth is based on depletable sources, and once they are depleted, a growth crisis is imminent. This points to the aspect of the interdependence of the individual components of extensive growth, which sooner or later lead to its slowdown. This interdependence arises in the sphere of a purely physical relationshi This means that the systems unable to generate an increase in efficiency (global productivity) can only achieve lower capital growth rates and, due to convergence, a lower output growth rate (Madžar, 1990, 152).
As a consequence of convergence, in the long run, the growth rate of the domestic product is equal to the capital growth rate. As a result, the incremental capital-output ratio $(\overline{\mathrm{k}})$ has a constant value. In the short term, these rates may differ from the marginal capital-output ratio $(k)$. It can easily be proved by the simple Harrod-Domar growth model.

If the investment $I(t)$ equals the accumulation $S(t)$, and if $S(t)=s \cdot Y(t)$, it follows:

$$
\begin{aligned}
& r_{K}=\frac{I(t)}{K(t)}=\frac{s \cdot Y(t)}{K(t)}=\frac{S}{\bar{k}(t)} \quad \text { and } \\
& r_{Y}=\frac{Y(t)}{Y(t)}=\frac{Y(t)}{I(t)} \cdot \frac{I(t)}{Y(t)}=\frac{S}{k(t)}
\end{aligned}
$$

If the rate of accumulation (s) is given and constant, the capital growth rate equals the quotient of the rate of accumulation and the incremental capital-output ratio $\overline{\mathrm{k}}(1)$. At the same time, the growth rate of the national income is equal to the quotient of the same rate of accumulation (s) and the marginal capital-output ratio $(k)(2)$. By comparing these equations, it is possible to:

$$
\begin{array}{ll}
\mathrm{r}_{\mathrm{K}}>\mathrm{r}_{\mathrm{Y}} & \overline{\mathrm{k}}(\mathrm{t})<\mathrm{k}(\mathrm{t}) \\
\mathrm{r}_{\mathrm{K}}=\mathrm{r}_{\mathrm{Y}} \quad \mathrm{i} & \overline{\mathrm{k}}(\mathrm{t})=\mathrm{k}(\mathrm{t}) \\
\mathrm{r}_{\mathrm{K}}<\mathrm{r}_{\mathrm{Y}} & \overline{\mathrm{k}}(\mathrm{t})>\mathrm{k}(\mathrm{t})
\end{array}
$$

If the marginal capital-output ratio $(\mathrm{k})$ is greater than the average $\overline{\mathrm{k}}[\mathrm{k}>\overline{\mathrm{k}}]$, the incremental capital-output ratio $(\overline{\mathrm{k}})$ increases.

Proof: If $\mathrm{k}>\overline{\mathrm{k}}$, then (bearing in mind (1) and (2), the growth rate of the domestic product $r_{Y}$ is lower than the capital growth rate $r_{K}\left[r_{Y}<r_{K}\right]$. Since the incremental capital-output ratio $\overline{\mathrm{k}}=\mathrm{K}(\mathrm{t}) / \mathrm{Y}(\mathrm{t})$, and the numerator grows faster than the denominator, $\overline{\mathrm{k}}$ is increased, and vice versa. The same result can be confirmed by the standard ratio of incremental and marginal values.

At a constant rate of accumulation (s), the capital growth rate $\left(\mathrm{r}_{\mathrm{K}}\right)$ cannot in the long term remain higher (or lower) than the growth rate of the domestic product $\left(r_{\gamma}\right)$. 
Proof: Since $r_{K}=s \cdot Y(t) / K(t)$, if $r_{K}>r_{\gamma^{\prime}}$ the denominator grows faster than the numerator, and $r_{\mathrm{K}}$ must fall, approaching $r_{\gamma}$. In an analogous way, the convergence of rate $r_{K}$ towards rate $r_{Y}$ is achieved, when $r_{K}<r_{Y^{\prime}}$ at the constant rate of accumulation (s). This proves convergence at a constant rate (s).

Furthermore, it is necessary to show a tendency of the decreasing of rate $r_{K^{\prime}}$ where $r_{K}>r_{Y}$, in conditions when the rate of accumulation (s) is variable.

Proof: If: $r_{K}=\frac{S(t) \cdot Y(t)}{K(t)}$,

then: $r\left(r_{K}\right)=r_{S}+\left(r_{Y}-r_{K}\right)$

When $r_{K}>r_{Y^{\prime}}$ in the expression $r\left(r_{K}\right)$ there will be a negative component $\left(r_{Y}-r_{K}<0\right)$ and a downtrend of $r_{K}$. This decline may partially be compensated by the growth of the rate of accumulation $\left(r_{s}>0\right)$. However, this compensation cannot be complete, because the definitional upper limit for $\mathrm{s}$ is 1 . The possible effect of the relationship $r_{s}>0$ will sooner or later be overcome and $\left(r_{Y}-r_{K}<0\right)$. This negates the effect of the $r_{s}>0$ rate, and the $\mathrm{r}\left(\mathrm{r}_{\mathrm{K}}\right)<0$ rate. That means that the capital growth rate will approach the rate of the growth of the domestic product from above.

In circumstances where $r_{K}<r_{Y^{\prime}}$ it cannot permanently be compensated by a possible reduction in the rate of accumulation $\left(\mathrm{r}_{\mathrm{s}}<0\right)$.

Proof: If $r_{K}<r_{Y^{\prime}}$ then $r_{Y}-r_{K}>0$. This can be compensated by reducing the rate $s\left(r_{s}<0\right)$. However, since the rate of accumulation (s) has a zero as its definitional limit, it means that sooner or later there will be convergence $r_{K} \rightarrow r_{Y}$. This proves convergence $r_{K} \rightarrow r_{Y}$ in the case of the constant and variable rate of accumulation (s).

From the long-term standpoint, the only relevant case is the case of constant rate $s$, because its possible increase may only be temporary. At a constant rate s, it is possible for $r_{K}$ to grow, thus partially compensating for a decline in labour and the efficiency growth rate. That compensatory growth may only be temporary.

Proof: If $r_{K}=s \cdot Y(t) / K(t)$, an increase in the capital growth rate $r\left(r_{K}\right)>0$ implies that $r_{Y}>r_{K}$. Taking into account (1) and (2), this means that $\mathrm{k}<\overline{\mathrm{k}}$, implying a decline of $\overline{\mathrm{k}}$. The declining incremental capital- output ratio $\overline{\mathrm{k}}$ will begin to approach limit $k$, because the latter cannot constantly be reduced. This means that the distance between them will decrease $(\overline{\mathrm{k}}-\mathrm{k}) \rightarrow 0$, i.e. will tend to zero. (1) and (2) show that in this case the difference between the growth rates $r_{Y}$ and $r_{K}$ is reduced, so it follows that the difference between growth rates will tend to zero: $\left(r_{Y}-r_{K}\right) \rightarrow 0$. This means that the capital growth rate $\left[\mathrm{r}\left(\mathrm{r}_{\mathrm{K}}\right)\right]$ will stay in the zone of positive values, and become smaller, i.e. its growth rate is negative. This means that the capital growth continues to accelerate, but that the pace of the acceleration is smaller. This phenomenon of acceleration gradually disappears and the growth rate $r_{K}$ tends to a constant value.

The empirical results of some studies are consistent with these theoretical postulates (Gavrilović-Jovanović, 1989; Madžar, 1990). Specifically, the results show that some economies intensify their investment activity by trying to compensate for the unfavourable impact of certain factors (primarily low efficiency) by the growth of capital. However, the effects of such an increased investment activity, in an effort to compensate for the unfavourable impact of certain factors (low efficiency) by the growth of capital, are limited and relatively quickly depleted.

An increase in the investment activity in an attempt to compensate for the depressing impact of unfavourable factors by the growth of capital is limited and relatively quickly depleted. Experience has shown that, in economies following a strategy of extensive growth, the incremental capital-output ratio increases (Chan, Karceski \& Lakonishok, 2002). Therefore, the marginal capital-output ratio is higher than the average, and the capital growth rate $\left(r_{K}\right)$ is greater than the growth rate of the domestic product $\left(r_{\gamma}\right)$. Therefore, the capital growth rate $\left(r_{K}\right)$ is reduced, and this decline is pressing down on the rate $r_{\gamma}$. It is easy to prove that an increase in the investment rate, when it exceeds a certain limit, leads to a decrease rather than an increase in the growth rate: $r\left(r_{Y}\right)=r_{S}-r_{K}$. When $k$ starts to grow faster than $s$, the growth rate $r_{Y}$ begins to decrease, due to the efforts to increase investments.

Specifically, an increase in the incremental capital-output ratio $(\bar{k})$ implies that $r_{K}>r_{Y}$. Since $r\left(r_{K}\right)=r_{s}+r_{Y}-r_{K}$ and since $r_{S}$ typically equals zero (it 
equals zero if, in order to mitigate the slowdown of growth, the strategy to increase the rate of accumulation is approached), it follows that $r\left(r_{K}\right)<0$, i.e. the capital growth rate $\left(r_{K}\right)$ decreases. The speed of a decrease is dependent on whether the gap between $\overline{\mathrm{k}}$ and $\mathrm{k}$ decreases. This is precisely the reason why the capital growth rate decreases. The decrease of $r_{K}$ exerts pressure on the decrease of the growth rate $r_{\gamma}$. That means that, as long as the incremental capital-output ratio $(\overline{\mathrm{k}})$ increases, the limit is higher than the average, so, sooner or later, that the latter has to grow, implying an impact on the decrease of the rate $r_{Y}$.

The typical reaction of some economies is to compensate a decrease in efficiency, manifested by an increase in the incremental capital-output ratio, by increasing the rate of accumulation (Ristić i Tanasković, 2013, 88). It may temporarily postpone and partially mitigate the observed effect, but cannot prevent it until the relationship between the domestic product and capital $(\mathrm{Y} / \mathrm{K}$ - productivity or the efficiency of capital) deteriorates, which proves Hypothesis H2. Certain interventions can mitigate, but not reverse the fundamental and exogenously determined trends. It can, therefore, be concluded that these are mechanisms that cannot lead to a permanent increase in economic efficiency.

The convergence of rates $r_{K}$ and $r_{Y}$ can be realised in many different ways. It can be achieved through high or low growth rates, the system can quickly be lowered to low equilibrium rates or it can approach them slowly and gradually (Lawrence \& Williamson, 2014, 215). If a decline in the capital growth rate is inevitable in the long run as a result of declining and low efficiency (technical progress), there is an additional short-term mechanism in which the causal relationship goes in the opposite direction. A slowdown in the capital growth implies less chance for technical progress. That means that the long-term capital growth slowdown caused by poor technical progress (efficiency) contains a short feedback loop in which a slowdown in capital adversely affects the rate of technical progress.

The issue of efficiency comes down to effectiveness with which an available economic potential is used. A strategy of a forced increase in quantities cannot permanently replace a lack of motivation, creativity, and thus based increase in business efficiency. Even with stagnant efficiency, it is not possible to maintain the desirable and for the market economy usual pace of growth.

However, there is no such matter as a perfect measure of efficiency, whereas the standard and commonly used methods of measuring efficiency include not so few and not so negligible analytical limitations. For example, natural resources, because of their diversity, which can be characterised as immeasurability, are usually left out. Then, the influence of foreign funds is generally not taken into account to the fullest. The effects of using additional capital coming from abroad come to the fore only to the extent to which they are expressed through an increased value of production funds, but their impact on an overall increase in efficiency remains largely outside the scope of performance indicators.

\section{CONCLUSION}

Economic development in all its complexity cannot be understood if the significant effects of various exogenous circumstances, which typically affect the growth rate, are not considered and taken into account. Pointing to this complex mechanism of interdependence is considered to be the basic contribution of this paper. The above arguments, on the basis of which growth rates, regardless of what kind, do not reflect the development efforts or the efficiency of economic and system solutions in the intervals in which they were recorded, seem to be quite clear and relevant. „The growth rate is a necessary but not sufficient indicator of economic growth" (Gavrilović-Jovanović, 1989, 65). A pace of growth can significantly be increased at the expense of its quality. Sooner or later, substandard growth causes a slowdown of economic growth, which proves that temporary acceleration can be achieved at the expense of future and long-term growth rates. In addition, we have pointed out that the strategy of extensive growth includes the factors that inevitably lead to its slowdown, because it is based on the mechanisms that cannot ensure a permanent increase in economic efficiency. Not even the intensification of investments 
can sustain growth at a desirable and necessary level. This means that the deceleration of growth is not a coincidence, but rather a legal consequence of the essential logic of the functioning of such a system.

We believe that the knowledge of the complex mechanism of the interdependence of growth rates is especially beneficial to economic policy holders and makers of development strategies. They in particular have to keep in mind that high growth rates in the current period may represent an exchange of the future for the present, but under adverse circumstances when a future growth is sacrificed for the sake of the current growth. Specifically, without increasing the quality of growth (efficiency), the whole development process is doomed to deceleration and long-term stagnation, and only growing efficiency allows for the sufficient long-term valorisation of the investment activity, as a traditionally abundant source of growth.

However, the measure and indicators of the quality of growth, in theoretical and methodological terms, are not clearly defined, which is the key limitation of this study, but also a relevant issue for future research. The field of efficiency is huge and vast in its truest sense. Therefore, there are no chances for its depletion nor can there be any such chances, not even at the level of the most general components. It should be noted that the quality of growth and efficiency are the key guidelines for further research in economic growth. Insisting on the qualitative aspects of growth, of course, is not aimed at questioning the importance of high growth rates, particularly in economies at a lower level of development. The first task of a quantitative analysis of sources of growth is to identify the factors that affect the pace of the growth of production. In addition, it should be noted that the negligence of the quality of growth is directly linked with costs. Specifically, besides implying difficulties in the measuring of a decline in social welfare, a lower quality implies higher running expenses and other types of costs.

The main contribution of this paper is the identification of the phenomenon of the temporal interdependence of growth rates, achieved in successive intervals of the observed period, as an almost universal system of interdependence. However, the same mechanism of interdependence is very complex in its action, so that in different situations there are different mechanisms. Generally speaking, the success of economic growth in any period, as a rule, cannot be measured by the rate of growth achieved only during this period. Because of the temporal interdependence of the series of growth rates, any specifically observed rate reflects the relevant characteristics of the development processes in the past and affects the development conditions and chances of achieving a satisfactory pace of growth in the future, too. There are several sources and reserves of growth that can be depleted in a given period, at the expense of (or in favour of) the development potential that remains available for future periods.

\section{REFERENCES}

Chan, L. K. C., Karceski, J., \& Lakonishok, J. (2002). The Level and Persistence of Growth Rates. The University of Illinois, Washington University and the Western Finance Association.

Denison, E. F. (1984). Accounting for Slower Economic Growth. Washington, USA: The Brookings Institution.

Denison, E. F., \& Poullier, J. (1967). Why the Growth Rates Differ. Washington, USA: The Brookings Institution.

Denison, E. F., Jorgenson, D. W., \& Grilichers, Z. (1972). The Measurement of Productivity. Washington, USA: The Brookings Institution.

Gavrilović-Jovanović, B. (1989). Kvalitet privrednog rasta. Beograd, Srbija: Savremena administracija.

Gligorić, M. (2013, decembar). Priliv stranih direktnih investicija u Srbiju: Novi izazovi u periodu krize. Rad prezentiran na konferenciji: Ekonomske politike Srbije u 2014: Mogućnosti privrednog rasta u uslovima reformi i fiskalne konsolidacije, Ekonomski fakultet Univerziteta u Beogradu, Beograd, Srbija.

Hansen, L., \& Hodrick, R. (1980). Forward exchange rates as optimal predictors of future spot rates: An econometric analysis. The Journal of Political Economy, 88(5), 829-853.

Komazec, S., i Ristić, Ž. (2009). Ekonomija kapitala i finansiranje razvoja. Beograd, Srbija: EtnoStil.

Komazec, S., i Ristić, Ž. (2011). Makroekonimija - makroekonomske teorije i makroekonomska analiza. Beograd, Srbija: EtnoStil.

Lawrence, H. O., \& Williamson, S. H. (2014). Annualized Growth 
Rate of Various Historical Economic Series. MeasuringWorth

Madžar, Lj. (1990). Suton socijalističkih privreda. Beograd, Srbija: Ekonomika i Institut ekonomskih nauka.

Madžar, Lj. (1981). Međuzavisnost i uporedivost stopa rasta u raznim periodima. Ekonomska misao, 14(3).

Mawson, (2002). Measuring Economic Growth in New Zealand. New Zealand Treasury Working Paper 02/14.

Petrović, P., Bajec, J., Živković, B., Arandarenko, M., Arsić, M. i drugi (2010). Postkrizni model ekonomskog rasta i razvoja Srbije 2011-2020. Beograd, Srbija: Fond za razvoj ekonomske nauke, Ekonomski fakultet Univerziteta u Beogradu.

Publishing OECD (2012). Economic Policy Reforms: Going for Growth.

Republički zavod za statistiku (2013). Aktuelni pokazatelji rasta. Beograd, Srbija.

Rikalović, G. (2010). Razvojna i ekonomska politika i kreativni kapital. Škola biznisa, 7(2), 26-32.
Ristić, B., i Tanasković, S. (2013, decembar). Strategija za unapređenje konkurentske pozicije Srbije prema kompozitnim merilima - primer indeksa globalne konkurentnosti. Rad prezentiran na konferenciji: Ekonomske politike Srbije $\mathrm{u}$ 2014: Mogućnosti privrednog rasta u uslovima reformi i fiskalne konsolidacije, Ekonomski fakultet Univerziteta $\mathrm{u}$ Beogradu, Beograd, Srbija.

Average AnnualGrowth Rate(AAGR): www.investinganswers. com/financial-dictionary/investing/average-annualgrowth-rate-aagr-2549

Definition of Economic Growth Rate www.investopedia.com/ terms/e/economicgrowthrate.asp

Growth Rates and Terminal Value: people.stern.nyu.edu/ adamodar/pdfiles/ovhds/dam2ed/growthandtermvalue.pdf

Relative Rates of Growth: www.math.psu.edu/files/141rates1. pdf

Received on $16^{\text {th }}$ April 2014, after two revisions, accepted for publication on $19^{\text {th }}$ August 2014.

Nada Trivic is a Full Professor at the Faculty of Economics in Subotica, University of Novi Sad, Serbia. She teaches the subjects of Microeconomics and Microeconomic Models. She has authored and coauthored several student textbooks and scientific monographs, as well as several tens of papers published in journals and numerous papers presented at both international and national conferences.

Viktorija Petrov is a Teaching Assistant at the Faculty of Economics in Subotica, University of Novi Sad, Serbia. She teaches the subjects of Microeconomics and Microeconomic Models. She is a student of the doctoral studies at the Faculty of Economics, University of Belgrade, Serbia. 


\title{
USLOVLJENOST STOPA EKONOMSKOG RASTA KVALITETOM RASTA
}

\author{
Nada Trivić*, Viktorija Petrov \\ Ekonomski fakultet u Subotici, Univerzitet u Novom Sadu
}

Svaka konkretna stopa ekonomskog rasta ukazuje na relevantne karakteristike tekućih razvojnih procesa, ali se, takođe, odražava na šanse dostizanja zadovoljavajućeg tempa privrednog rasta u budućnosti. Dakle, reč je o opštoj međuzavisnosti i zakonitosti konvergencije stopa rasta. Osnovni cilj ovog rada je da pokaže da nekvalitetan rast, pre ili kasnije, izaziva usporavanje privredne dinamike, i da privremeno ubrzanje rasta može biti postignuto na račun dugoročne stope rasta. Naučni instrumentarijum primenljiv za ostvarivanje ovako postavljenog cilja istraživanja je metod analize, istorijski metod i metod komparativne analize, kao i brojne tehnike u vidu savremenih informacionih sredstava. Ključni rezultat ovog istraživanja je da bez istovremenog povećanja efikasnosti upotrebe resursa, sve stope rasta endogenih faktora proizvodnje konvergiraju aritmetičkoj sredini stopa rasta egzogenih proizvodnih činilaca. Dakle, tempo rasta se može bitno povećati na uštrb njegovog kvaliteta, a rast neodgovarajućeg kvaliteta sadrži klice vlastitog zaustavljanja.

Ključne reči: stopa rasta, konvergencija, efikasnost, kvalitet rasta, međuzavisnost stopa rasta

\section{UVOD}

Standardna je i donekle trivijalna konstatacija da je privredni razvoj izuzetno složen i po svojoj prirodi višedimenzionalan fenomen. Pokušaji njegovog merenja nailaze na velike konceptualne i metodološke teškoće i razlike $u$ primeni i tumačenju (Average Annual Growth Rate: www.investinganswers.com). Neki aspekti razvoja su potpuno nemerljivi, drugi su delimično merljivi, a neki, pak, omogućavaju tolike

\footnotetext{
* Korespondencija: N. Trivić, Ekonomski fakultet u Subotici, Univerzitet u Novom Sadu, Segedinski put 9, 24000 Subotica, Srbija; e-mail: ntrivic@ef.uns.ac.rs
}

slobode i proizvoljnosti da bi u nekim slučajevima bolje bilo da se i ne mere. Svakako, bitan element privrednog razvoja je privredni rast. Pod ekonomskim (privrednim) rastom se podrazumeva porast proizvodnje, proizvodnih kapaciteta i svih drugih segmenata privrede. Ekonomski rast je porast ukupnog outputa privrede. Najčešće se tempo privrednog rasta meri i izražava stopom rasta. Međutim, stope rasta, kao razvojni pokazatelj, sadrže brojna ograničenja:

- izračunavaju se na osnovu polaznih podataka različitog kvaliteta i verodostojnosti;

- osetljive su na opseg i dubinu strukturnih promena; 
- statistika ima brojne mogućnosti za manipulacije i doterivanje oficijelno prezentovanih podataka na osnovu kojih se stope rasta izračunavaju;

- empirijski rezultati sugerišu vezu između nivoa i tempa rasta, pa stope rasta nisu uporedive kada se posmatraju zemlje različitog nivoa razvijenosti;

- različita tehnološka rešenja i iskustva pojedinih zemalja čine da stope rasta postaju neuporedive;

- neke zemlje mogu imati relativno visoke stope rasta, a da se iz tih cifara ne vidi da su razvojne rezerve iscrpljene;

- stope rasta, kao cifre, ne govore o kvalitetu rasta, pa tako kvalitet kao ogromno, ali nemerljivo područje ostaje u senci, a važan je aspekt bar koliko i kvantitet.

Osnovni cilj ovog rada je da pokaže da ekstenzivni rast (zasnovan na radnoj snazi i prirodnim resursima) sadrži klice vlastitog zaustavljanja, iscrpljivanja egzogenih izvora rasta. Stoga se mora govoriti i o kvalitetu rasta (Denison, Jorgenson \& Grilichers, 1972, 157). Analiza kvaliteta rasta je posebno značajna u uslovima brze privredne ekspanzije kada se lako izvode povoljni zaključci, a visoka stopa rasta nije garant njegovog kvaliteta. Drugi cilj ove analize je da pokaže da se nekvalitetan rast ispoljava kao ograničavajući faktor povećanja proizvodnje $u$ budućnosti, zbog vremenske međuzavisnosti stopa rasta. Mada, ako jedna privreda na duži rok postiže brz rast, ima osnova za pretpostavku da je taj rast kvalitetan (Mawson, 2002, 432). Pored toga, analiza privrednog rasta je, po svojoj prirodi, dugoročna, pa se pri posmatranju kraćih perioda mora imati u vidu vremenska međuzavisnost stopa rasta.

Polazeći od metodologije izračunavanja stopa rasta i navedenih ograničenja, mogu se postaviti sledeće dve hipoteze:

$\mathrm{H} 1$ : Stope rasta u različitim posmatranim periodima su vremenski međuzavisne i uslovljene kvalitetom rasta.

H2 : U uslovima ekstenzivnog rasta postoji konvergencija stopa rasta.
Postavljene hipoteze, naizgled nesporne, uz objašnjenja bazirana na ekonomskoj teoriji, ali i uz neke rezultate iz prakse, postaju sasvim prihvatljive. Više od toga: otvaraju brojna pitanja relevantna za institucionalna rešenja i mere ekonomske politike gotovo svake privrede, a $\mathrm{u}$ nekim segmentima postaju deo fundamentalnih ekonomskih znanja. S obzirom da su definisane hipoteze teorijsko-metodološkog karaktera, $\mathrm{u}$ ovom istraživanju na raspolaganju su brojne naučne metode. Međutim, sam predmet istraživanja opredelio je dominantno primenu metoda naučne analize, istorijskog metoda i metoda komparativne analize, kao i brojne tehnike u vidu savremenih informacionih sredstava.

Iz definisanih hipoteza, a u skladu sa osnovnim ciljevima rada, proistekla je njegova struktura: u prvom delu se ukazuje na vremensku međuzavisnost stopa rasta, a u drugom delu na konvergenciju stopa rasta. Oba dela analize upućuju na zaključak o značaju efikasnosti, kao ključnom ekonomskom problemu.

\section{VREMENSKA MEĐUZAVISNOST STOPA RASTA}

Najčešće se efikasnost privrednog razvoja posmatra kroz nivo i promene tempa rasta. Međutim, ako se $\mathrm{u}$ analizu pored nivoa rasta uvedu i promene njegovog tempa, ukupan postupak se relativizira, a dobijene ocene su višeznačne. Odnosno, ista stopa rasta se može različito oceniti, zavisno od toga da li joj prethode visoke ili niske stope rasta. Treba reći da svaka konkretno posmatrana stopa odražava relevantne karakteristike tekućih razvojnih procesa, ali se, takođe, odražava i na razvojne uslove i šanse dostizanja zadovoljavajućeg tempa rasta u budućnosti.

Mera u kojoj se data stopa rasta tumači kao uspešna, na vrlo složen način zavisi od celokupne konfiguracije stopa rasta zabeleženih $\mathrm{u}$ prethodnom periodu. Pored toga, učinak jednog perioda se ceni, ne samo po neposrednim rezultatima koji su unutar tog perioda registrovani, već i po dinamičkom potencijalu koji će preneti $u$ naredno razdoblje (Growth Rates and Terminal Value: www.stern.nyu. edu/.../growthandtermvalue.pdf). Dakle, potrebno ga 
je ceniti i po tome u kojoj meri je pripremio teren za ostvarivanje povoljnih budućih stopa rasta.

U određenom periodu, skup institucionalnih rešenja može dati dobre rezultate, ali da istovremeno sadrži (kao tendenciju ili mogućnost) elemente koji mogu smanjiti buduće razvojne performanse (Denison \& Poullier, 1967, 132-137). Takav skup institucionalnih rešenja omogućava dostizanje visokih stopa rasta, ali sadrži i potencijal stvaranja novih rešenja koja će te stope bitno smanjiti u budućnosti. U nekom periodu se može isforsirati brz rast, ali tako da se razvojne mogućnosti u narednom periodu neminovno drastično smanjuju, ili čak da se onemogući bilo kakav razvoj. Situacija je obrnuta ukoliko tekući period baštini povoljne razvojne mogućnosti iz prethodnog perioda (Denison, 1984, 82). Tada se stopa rasta u prethodnom periodu, ako se uzima kao indikator uspešnosti, mora diskontovati za toliko koliko je taj razvojni proces umanjio šanse za postizanje zadovoljavajuće stope $u$ sadašnjem periodu. Ista logika važi i za budućnost. Ova međuzavisnost je posebno aktuelna u privredama koje karakterišu periodi niskih stopa rasta, ekonomske stagnacije, ali i periodi relativno (pa i naglašeno) visokih stopa rasta (Komazec i Ristić, 2011, 133).

Često se razvojna politika mora neko vreme orijentisati na teška, mučna i mukotrpna strukturna i druga prilagođavanja. U meri u kojoj niska stopa rasta koja proističe iz takvih prilagođavanja, zapravo, priprema teren za uspešan razvoj $u$ budućnosti, takva stopa rasta se, i pored skromnog nivoa, može tumačiti kao značajan rezultat ekonomske politike. Dakle, uspešnost razvoja jednog perioda nije nezavisna od razvojnih trendova i performansi u prošlosti i u budućnosti. Reč je o "fenomenu vremenske međuzavisnosti stopa rasta ostvarenih $\mathrm{u}$ sukcesivnim intervalima posmatranog razdoblja" (Madžar, 1981, 38). Usled opšte međuzavisnosti, svaka konkretno posmatrana stopa rasta odražava relevantne karakteristike razvojnih procesa u prošlosti i utiče na uslove razvoja i tempo rasta $\mathrm{u}$ budućnosti. Niske stope rasta zabeležene $\mathrm{u}$ nekom periodu, između ostalog, mogu biti posledica prevelike zaduženosti, a relativno visoke ostvarene stope rasta, zabeležene u prethodnim periodima, bile bi niže da se nisu povećavale na račun tekućih (niskih) stopa.
Samo kao idealan i hipotetički model, ali uz vrlo restriktivne pretpostavke, moguće je zamisliti razvojni proces $\mathrm{u}$ kome su stope rasta isključivi rezultat mera i poduhvata preduzetih upravo $\mathrm{u}$ tom periodu. Tada bi se, uz vrlo nerealne pretpostavke, dobili pokazatelji rasta $\mathrm{u}$ vidu stopa rasta koje bi se tumačile kao indikatori razvoja u posmatranom periodu i nezavisno od perioda koji su prethodili i koji slede. U stvarnosti takvih slučajeva nema, a posebno ne u privredama koje su izložene brojnim egzogenim šokovima, naglim i brojnim preokretima u politici, ali i mukotrpnom procesu institucionalne izgradnje.

Mehanizam vremenske međuzavisnosti stopa rasta je vrlo kompleksan, a deluje kroz određene (nekad nezavisne) sprege makroekonomskih agregata. Kao osnovni mogu se izdvojiti sledeći mehanizmi:

- zaduživanje u inostranstvu,

- uvozna zavisnost,

- promena strukture investicija,

- erozija kapitala u inflatornim uslovima,

- troškovi eksploatacije prirodnih resursa i iscrpljivanje zaliha, $\mathrm{i}$

- međuzavisnost institucionalnih rešenja.

\section{Zaduživanje $u$ inostranstvu}

$\mathrm{U}$ određenom periodu investicije se mogu naglo povećati, ako je ekonomska politika orijentisana na strategiju intenzivnog zaduživanja. U vidu prirasta proizvodnje došlo bi do povećanja stope rasta, ali to nije znak uspešne ekonomske politike. Ti porasti proizvodnje su rezultat resursa koji potiču iz drugih privreda. Kada se iscrpi priliv inostranih sredstava i nastupi faza otplate duga, investicioni potencijal privrede naglo pada, nastupa deceleracija rasta, kao posledica isforsirane i na tuđim sredstvima bazirane (prethodne) akceleracije ili umanjenja budućeg razvojnog potencijala (Relative Rates of Growth: www. math.psu.edu/files/141rates1.pdf).

Ukoliko su, uz to, pozajmljena sredstva neadekvatno upotrebljena, to dodatno umanjuje ukupne efekte. Za ilustraciju tih efekata nije potreban model ili 
mašta, dovoljan je uvid u ono što se dešava u privredi Republike Srbije (Republički zavod za statistiku, 2013, Aktuelni pokazatelji rasta). Nameće se zaključak da je niska stopa rasta uslovljena i prevelikom zaduženošću, ali i da bi stope rasta $u$ nekim prethodnim periodima bile daleko niže da se nisu povećavale na račun sadašnjih, niskih stopa.

\section{Uvozna zavisnost}

Empirijski podaci pokazuju da su neke privrede već decenijama visoko uvozno zavisne. U takvim uslovima, obim proizvodnje i stopa rasta bitno zavise i od snabdevenosti uvoznim utrošcima. Tada su se neka ubrzanja rasta ostvarivala upravo zahvaljujući poboljšanju snabdevenosti uvoznim proizvodima, što se obezbeđuje iscrpljivanjem deviznih rezervi. Obično se smanjenje deviznih rezervi podudara sa povećanjem zaliha uvoznih sirovina i materijala. Međutim, takvo iscrpljivanje deviznih rezervi stvara pretpostavke za neminovno smanjenje tempa rasta $u$ budućnosti. Eventualno oživljavanje dinamike rasta u takvim uslovima, mora da čeka neko novo obnavljanje rezervi.

\section{Promena strukture investicija}

Različiti investicioni projekti imaju različite nizove stvarnih i očekivanih rezultata. Neki projekti daju rezultate već i u tekućoj godini, dok je kod drugih većina efekata u tekućoj godini mala, a veći pozitivni efekti se ostvaruju u trogodišnjem ili petogodišnjem periodu. Jasno je da su moguće brojne različite kompozicije projekata u svakom posmatranom periodu, pri istom obimu investicija, što rezultira i različitim prirastom proizvodnje, a to znači u različitim periodima i različite stope rasta.

U cilju ilustracije ideje o vremenskoj međuzavisnosti stopa rasta, pretpostavimo da se svi investicioni projekti klasifikuju u dve grupe: u prvoj grupi su projekti koji najveći deo svojih rezultata generišu u tekućoj i njoj bliskim godinama; $u$ drugoj grupi su projekti čiji se najveći efekti ostvaruju u relativno dugom roku. Jasno je da je moguće mnogo različitih kombinacija projekata sa različitim ulaganjima i rezultatima, a u pojedinim periodima te različite kombinacije projekata i pri istom obimu investicija daju bitno različite rezultate (Gligorić, 2013, 112). Ti rezultati mogu varirati od praktične stagnacije do naglog povećanja proizvodnje u istom ili drugim vremenskim intervalima. To će se, naravno, odraziti i na stope rasta u drugim periodima, manje ili više udaljenim od posmatranog.

Poseban oblik vremenske međuzavisnosti u tempu rasta jesu razlike $\mathrm{u}$ aktivizacionim periodima pojedinih projekata, kao i različit broj nezavršenih projekata iz jednog perioda $u$ drugi. Ako je masa nezavršenih projekata koju dati period nasledi od prethodnog velika i ako je povoljna distribucija vremena završetka i priticanja rezultata, vrlo je verovatno da će se $u$ posmatranom periodu ostvariti visoke stope rasta. Međutim, takve stope rasta nisu rezultat napora i politike posmatranog perioda, već neka vrsta nasleđa ili poklona prenetog iz prošlosti. Ali, moguća je i obrnuta situacija: da se u sadašnjem periodu ulaže i dodaje masi nedovršenih projekata, a sa ciljem da se uveća budući razvojni potencijal. Tada će sadašnja stopa rasta u nekoj meri biti umanjena, ali će se preduzete mere i akcije valorizovati u budućnosti, kroz više stope rasta u narednom periodu.

Pored toga, neke investicije ne daju velike trenutne efekte, ili čak, kad je reč o infrastrukturnim ulaganjima, neposredne efekte uopšte ne daju. Te investicije, međutim, na dugi rok generišu mnoštvo posrednih efekata, a posebno kroz mogućnost efikasnijeg privređivanja (jeftiniji i brži prevoz, bolje komunikacije, razvijeni i pouzdani informacioni sistemi, itd.), smanjuju troškove širokoj lepezi privrednih delatnosti, pa i privredi kao celini. Kada se "uštedi" na tim ulaganjima, budući eksploatacioni troškovi su daleko veći nego što bi objektivno mogli biti, a privreda kroz povećane tekuće troškove plaća visoku kamatu na sredstva koja je „pozajmila” od infrastrukturnih delatnosti i uložila $u$ neposredno proizvodne aktivnosti sa bržim i kratkoročnim efektima. Pored toga, troškovi neefikasnog funkcionisanja sistema su uvek veliki, mada dobrim delom nevidljivi i na operativan način nemerljivi. Oni iscrpljuju privredu i stanovništvo, a time smanjuju ekonomski potencijal, praktično umanjuju raspoloživa sredstva, čime onemogućavaju da se umanjeni investicioni potencijal efikasno iskoristi. 


\section{Erozija kapitala u inflatornim uslovima}

Erozija kapitala $\mathrm{u}$ inflatornim uslovima je zanimljiv mehanizam međuzavisnosti tempa rasta. Kako praksa nedvosmisleno pokazuje, $\mathrm{u}$ inflatornim uslovima dolazi do nevidljive i računovodstveno neobuhvaćene erozije kapitala.

U inflatornim uslovima iskazani društveni proizvod je precenjen, jer se nevidljivo smanjenje društvenog kapitala iskazuje kao dodatak društvenom proizvodu (Komazec i Ristić, 2009, 118). Time se deformišu i stope rasta. Na primer, obračun amortizacije, koji ne omogućuje očuvanje neto vrednosti kapitala, doprinosi precenjivanju dodatne vrednosti na račun društvenog bogatstva. Potcenjivanje indeksa rasta cena doprinosi precenjivanju indeksa količina, a time, u krajnjoj liniji, i stopa rasta.

Vrlo karakteristična je i erozija obrtnih sredstava. U inflatornim uslovima, logika obračuna i očuvanja nominalnih vrednosti ima direktnu posledicu da ista ili veća novčana sredstva nisu dovoljna za obnovu realnih obrtnih sredstava neophodnih za nesmetan tok reprodukcije.

\section{Troškovi eksploatacije prirodnih resursa i iscrpljivanje zaliha}

Poznato je da se prirodna bogatstva praktično ne mere i ne iskazuju postojećim sistemom računovodstva. Iskazani društveni proizvod ne odražava količinu nepovratno utrošenih neobnovljivih resursa. Vremenom se, na primer, iscrpljuju pojedina nalazišta ruda, vrši se eksploatacija teže dostupnih i skupih naslaga, što smanjuje društveni proizvod i tempo njegovog rasta. To se posebno odnosi na kvalitet investicionih dobara, kod kojih se ušteda ostvarena na štetu kvaliteta (u negativnom smislu) višestruko kompenzira većim eksploatacionim troškovima. Nekvalitetne sirovine i reprodukcioni materijal, takođe, podrazumevaju veće troškove, jer je proizvodnja teža, zastoji u proizvodnji češći i duži, uz moguće tehnološke komplikacije. Istovremeno, ranije iskazani društveni proizvod i tempo njegovog rasta očito bi bio precenjen, zbog ignorisanja troškova eksploatacije oskudnih resursa. Naravno, ove deformacije se unose u obračun stopa rasta.
Uticaj ovog mehanizma na stopu rasta bi se mogao eliminisati, ako bi postojao način da se knjigovodstveno odrede troškovi neobnovljivih prirodnih resursa i za njihov iznos umanji izračunata dodatna vrednost.

Zatim, ako se koriste nalazišta otkrivena u prošlosti i ne ulaže se u otkrivanje novih nalazišta, tada se štedi na investicijama, ali ostvareni efekti se dobijaju po cenu smanjenja razvojnog potencijala u budućnosti, kada se privreda nađe u situaciji da ne može zameniti iscrpljena nalazišta. To znači da se alokacijom investicionih sredstava na istraživanje i eksploataciju posredno utiče na izbor vremenskog profila stopa rasta po pojedinim periodima (Hansen \& Hodrick, 1980, 829-853).

Za analizu kratkoročnih kolebanja stopa rasta relevantan je i stepen korišćenja kapaciteta. Kada se proizvodnja „zahuktava”, u uzlaznoj fazi ciklusa, dolazi i do povećanja stepena korišćenja kapaciteta. Međutim, kada rezerve postanu iscrpljene, takav rast se ne može neograničeno produžavati. Isti efekat ima i iscrpljivanje zaliha.

\section{Međuzavisnost institucionalnih rešenja}

Razvojne performanse privrede po pojedinim periodima međusobno su povezane. Veze između njih se uspostavljaju i kroz institucionalne promene i način na koji jedan skup institucionalnih rešenja proizilazi iz drugog, prethodnog skupa. Interakcije između pojedinih institicionalnih rešenja su vrlo kompleksne i nepogodne za preciznu analizu, pa se ne mogu utvrditi ni njihove rigorozne propozicije (Petrović, Bajec, Živković, Arandarenko, Arsić, i drugi, 2010, 98). Međutim, sa sigurnošću se može govoriti o njihovom postojanju i značajnim posledicama njihovog delovanja.

Princip koji je osnova institucionalnih međuzavisnosti veoma je jednostavan. Određeni skup institucionalnih rešenja može $u$ određenom vremenskom periodu biti vrlo funkcionalan i davati izuzetno dobre rezultate. Međutim, on u sebi može sadržati (kao mogućnost ili tendenciju) elemente novih rešenja koja, kad jednom budu ugrađena $\mathrm{u}$ regulatorni sistem, mogu bitno smanjiti razvojne performanse, pa i one koje se iskazuju stopom rasta. Aktuelnosti ovog pitanja 
doprinosi i činjenica da su se $u$ nekim privredama $u$ određenom razdoblju dostizale stope rasta koje su (u to vreme) bile među najvišim u svetu, a poslednjih decenija se suočavaju sa stagnacijom, pa i krizom rasta (Rikalović, 2010, 128). Rast se usporava, stope rasta na mahove ulaze $\mathrm{u}$ zonu negativnih vrednosti, a kvalitativni indikatori razvojnih procesa pokazuju sve veću inferiornost $\mathrm{u}$ odnosu na razvijene privrede.

Pitanja na koje bi bilo poželjno odgovoriti glase: Kako se moglo desiti da u osnovi isti sistemi u nekim periodima budu uspešni, a potom vrlo neuspešni? Da li je moguće da gotovo isti institucionalni mehanizam pokaže visoku efikasnost $\mathrm{u}$ jednom, a vrlo nezadovoljavajuće učinke $u$ drugom periodu? Koliko se neki skup institucionalnih rešenja $i$ instrumenata može tretirati kao uspešan ako omogućava dostizanje visokih stopa rasta, ali istovremeno sadrži potencijal ili tendenciju stvaranja rešenja koja neminovno $\mathrm{u}$ budućnosti dovode do obaranja stope rasta? Institucionalne međuzavisnosti mogu, dajući osnov za uspešan razvoj u jednom periodu, osuditi na neuspeh razvojne napore koji slede.

Sistem uči u vremenu i sa vremenom (Madžar, 1990, 153). Proces prilagođavanja novim institucionalnim uslovima, takođe, zahteva vreme i podrazumeva dovoljno dug prelazni režim unutar koga efikasnost pada daleko ispod uobičajenog i standardnog nivoa. Zapravo, u ovom slučaju dolazimo na trag još jednom dodatnom mehanizmu vremenske međuzavisnosti stopa rasta: Odlaganjem promena izbegavaju se poremećaji i usporavanje rasta, ali sistem u celini sve više okoštava $i$ tone sve više $u$ kolotečini institucionalnih svojstava. Praktično, odlaganjem promena zatvara se dugoročna perspektiva razvoja. Reč je o još jednom mehanizmu kojim se dugoročna stopa rasta žrtvuje radi očuvanja njenog relativno visokog nivoa na kratak rok (Publishing OECD, 2012, 326). Polovične i/ili nedovršene promene ostavljaju prostor za buduće poremećaje i nove iteracije institucionalnih prilagođavanja. Ozbiljnim promenama pristupa se tek kada postanu neizbežne i neodgodive, a kao takve one ne dopiru do krajnjih uzročnika, već ostaju na površini, na nivou izvedenih problema. Materijalna kretanja su posledica institucionalnih mehanizama, pa institucionalne odrednice imaju karakter temeljnih i, za ekonomiste, krajnjih uzročnika, dok materijalni činioci imaju karakter izvedenih činilaca. Takođe, institucionalni okvir se može ceniti samo po rezultatima koje generiše ekonomski sistem kao celina, a institucionalni okvir je samo jedna od determinanti ukupnog ekonomskog ishoda, pa je gotovo nemoguće razlučiti doprinos sistema od doprinosa ostalih odrednica.

Postoji, dakle, nekoliko izvora i rezervi rasta koje mogu biti iscrpljene $u$ datom periodu, na račun budućeg (Chan, Karceski \& Lakonishok, 2002, 108). Stoga se nameće zaključak da percepcija stope rasta (kao razvojnog indikatora) zavisi od opšte konstelacije razvojnih performansi, a posebno od stopa ostvarenih neposredno posle posmatranog perioda, čime je dokazana hipoteza H1. Percepcija stope rasta (i drugih indikatora za koje važi ista argumentacija) zavisi od opšte konstelacije razvojnih performansi, a posebno od stopa ostvarenih neposredno pre i neposredno posle posmatranog perioda. Očigledno je da između stopa rasta u različitim periodima postoji vrlo složen, suptilan, ali i realan i uticajan odnos međuzavisnosti, koji čini neprimerenim izolovani tretman bilo koje stope rasta. To istovremeno znači i da razvojni procesi zahtevaju integralni pristup i celovitu analizu.

Dakle, uspešnost privrednog rasta u bilo kom periodu ne može se meriti stopom rasta postignutom samo $u$ tom periodu, s obzirom na vremensku međuzavisnost stopa rasta. Stopu rasta i druge razvojne indikatore ostvarene $u$ jednom periodu treba veoma oprezno $i$ sa puno kvalifikativa tretirati kao rezultat razvojnih i institucionalnih napora iz posmatranog perioda. Zbog vremenske međuzavisnosti stopa rasta, svaka od njih ima duboke korene ne samo u bližoj, već i u daljoj prošlosti (Definition of 'Economic Growth Rate': http:// www.investopedia.com/terms/e/economicgrowthrate. asp).

\section{KONVERGENCIJA STOPA RASTA}

Dosadašnja praksa pokazuje da ekstenzivan rast sadrži mehanizme svog vlastitog zaustavljanja, koji se baziraju na iscrpljivanju egzogenih izvora rasta (Madžar, 1990, 307). Kada se ti izvori iscrpe, rast se usporava uz tendenciju ka privrednoj stagnaciji. 
Ekstenzivni rast je baziran na iscrpljivim izvorima, a kada oni budu iscrpljeni, kriza rasta je neminovna. Ovim dolazi do izražaja onaj aspekt međuzavisnosti pojedinih komponenata ekstenzivnog rasta koje, pre ili kasnije, dovode do njegovog usporavanja. Ta međuzavisnost se javlja $u$ sferi materijalnih veza. To znači da sistemi nesposobni da generišu porast efikasnosti (globalne produktivnosti) mogu ostvariti samo niže stope rasta kapitala, a zbog konvergencije i nižu stopu rasta outputa (Madžar, 1990, 152).

Kao posledica konvergencije, na dugi rok, stopa rasta društvenog proizvoda se izjednačava sa stopom rasta kapitala. Usled toga, prosečni kapitalni koeficijent $(\overline{\mathrm{k}})$ ima konstantnu vrednost. Na kratak rok, ove stope se mogu razlikovati od graničnog kapitalnog koeficijenta $(k)$. To se može dokazati polazeći od HarrodDomarovog modela rasta.

Ako su investicije I(t) jednake akumulaciji $S(t)$ i ako je $S(t)=s \cdot Y(t)$, sledi:

$$
\begin{aligned}
& r_{K}=\frac{I(t)}{K(t)}=\frac{s \cdot Y(t)}{K(t)}=\frac{S}{\bar{k}(t)} \quad \mathrm{i} \\
& r_{Y}=\frac{Y(t)}{Y(t)}=\frac{Y(t)}{I(t)} \cdot \frac{I(t)}{Y(t)}=\frac{S}{k(t)}
\end{aligned}
$$

Ako je stopa akumulacije (s) data i konstantna, stopa rasta kapitala jednaka je količniku stope akumulacije i prosečnog kapitalnog koeficijenta $\overline{\mathrm{k}}$ (1). Istovremeno, stopa rasta nacionalnog dohotka jednaka je količniku iste stope akumulacije (s) i graničnog kapitalnog koeficijenta k (2). Poređenjem ovih izraza moguće je:

$$
\begin{array}{ll}
\mathrm{r}_{\mathrm{K}}>\mathrm{r}_{\mathrm{Y}} & \overline{\mathrm{k}}(\mathrm{t})<\mathrm{k}(\mathrm{t}) \\
\mathrm{r}_{\mathrm{K}}=\mathrm{r}_{\mathrm{Y}} \mathrm{i} & \overline{\mathrm{k}}(\mathrm{t})=\mathrm{k}(\mathrm{t}) \\
\mathrm{r}_{\mathrm{K}}<\mathrm{r}_{\mathrm{Y}} & \overline{\mathrm{k}}(\mathrm{t})>\mathrm{k}(\mathrm{t})
\end{array}
$$

Ako je granični kapitalni koeficijent $k$ veći od prosečnog $\overline{\mathrm{k}}[\mathrm{k}>\overline{\mathrm{k}}]$, to ima za posledicu da prosečni kapitalni koeficijent $(\overline{\mathrm{k}})$ raste.

Dokaz: Ako je k > k , tada je (imajući u vidu (1) i (2)), stopa rasta društvenog proizvoda $r_{Y}$ manja od stope rasta kapitala $r_{K}\left[r_{Y}<r_{K}\right]$. Pošto je prosečni kapitalni koeficijent $\overline{\mathrm{k}}=\mathrm{K}(\mathrm{t}) / \mathrm{Y}(\mathrm{t})$, a brojilac raste brže od imenioca to se $\overline{\mathrm{k}}$ povećava, i obrnuto. Isti rezultat se može potvrditi standardnim odnosom prosečnih i graničnih veličina.

Pri konstantnoj stopi akumulacije (s), stopa rasta kapitala $\left(r_{K}\right)$ ne može na dugi rok ostati veća (niti manja) od stope rasta društvenog proizvoda $\left(\mathrm{r}_{\mathrm{\gamma}}\right)$.

Dokaz: Pošto je $r_{K}=s \cdot Y(t) / K(t)$, ako je $r_{K}>r_{Y}$ znači da imenilac raste brže od brojioca, pa $r_{K}$ mora opadati približavajući se $r_{Y}$. Na analogan način se ostvaruje konvergencija stope $r_{K}$ prema stopi $r_{Y}$ kada je $r_{K}<r_{Y} u z$ konstantnu stopu akumulacije (s). Time je dokazana konvergancija uz konstantnu stopu (s).

Potrebno je dalje pokazati tendenciju opadanja stope $r_{K}$ kada je $r_{K}>r_{Y} u$ uslovima kada je stopa akumulacije (s) promenljiva.

Dokaz: Ako je: $\quad r_{K}=\frac{S(t) \cdot Y(t)}{K(t)}$ ，

tada je: $\quad r\left(r_{K}\right)=r_{S}+\left(r_{Y}-r_{K}\right)$

da je $r_{K}>r_{Y}$ u izrazu $r\left(r_{K}\right)$ javiće se negativna komponenta $\left(r_{Y}-r_{K}<0\right)$ i tendencija opadanja $r_{K}$. Ovaj pad može biti delimično kompenziran rastom stope akumulacije $\left(r_{s}>0\right)$. Međutim, ova kompenzacija ne može biti potpuna, jer definiciona gornja granica za $\mathrm{s}$ je 1 . Eventualni efekat relacije $r_{s}>0$ će pre ili kasnije biti nadvladan $\mathrm{i}\left(\mathrm{r}_{\mathrm{Y}}-\mathrm{r}_{\mathrm{K}}<0\right)$. Time se negira efekat stope $\mathrm{r}_{\mathrm{s}}>0$, a stopa $\mathrm{r}\left(\mathrm{r}_{\mathrm{K}}\right)<0$. Odnosno, stopa rasta kapitala približavaće se odozgo stopi rasta društvenog proizvoda.

U uslovima kada je $r_{K}<r_{Y}$ to ne može biti trajno kompenzirano eventualnim smanjenjem stope akumulacije $\left(\mathrm{r}_{\mathrm{s}}<0\right)$.

Dokaz: Ako je $r_{K}<r_{Y^{\prime}}$ tada je $r_{Y}-r_{K}>0$. To može biti kompenzirano smanjenjem stope $s\left(r_{s}<0\right)$. Međutim, pošto stopa akumulacije (s) ima nulu kao svoju definicionu granicu, to znači da će se pre ili kasnije javiti konvergencija $r_{K} \rightarrow r_{\gamma}$. Time je konvergencija $r_{K} \rightarrow$ $r_{Y}$ dokazana $u$ slučaju konstantne i promenljive stope akumulacije (s).

Sa stanovišta dugog roka, relevantan je jedino slučaj konstantne stope $s$, jer njeno eventualno povećanje može biti samo privremeno. Pri konstantnoj stopi $s$ 
moguće je da raste $r_{K}$ i da tako delimično kompenzira opadanje stopa rasta zaposlenosti i efikasnosti. Taj kompenzatorni rast može da bude samo privremen.

Dokaz: Ako je $r_{K}=s \cdot Y(t) / K(t)$, povećanje stope rasta kapitala $r\left(r_{K}\right)>0$ podrazumeva da je $r_{Y}>r_{K}$. Imajući $u$ vidu (1) i (2), to znači da je $\mathrm{k}<\overline{\mathrm{k}}$, pa time i opadanje $\overline{\mathrm{k}}$. Opadajući prosečni kapitalni koeficijent $\overline{\mathrm{k}}$ počeće da se približava graničnom $k$, jer ovaj ne može neprestano da se smanjuje. To znači da će se razmak između njih smanjivati $(\overline{\mathrm{k}}-\mathrm{k}) \rightarrow 0$, tj. teži nuli. Iz (1) i (2) se vidi da se tada smanjuje razlika između stopa rasta $r_{Y}$ i $r_{K^{\prime}}$ pa sledi da i razlika stopa rasta teži nuli: $\left(r_{Y}-r_{K}\right) \rightarrow 0$. To dalje znači da će stopa rasta stope rasta kapitala $\left[\mathrm{r}\left(\mathrm{r}_{\mathrm{K}}\right)\right]$, ostajući u zoni pozitivnih vrednosti, postajati sve manja, tj. da je njena stopa rasta negativna. Odnosno, rast kapitala nastavlja da se ubrzava, ali je tempo tog ubrzanja sve manji. Time fenomen ubrzavanja postepeno isčezava i stopa rasta $r_{K}$ teži konstantnoj vrednosti.

Empirijski rezultati nekih studija su u skladu sa ovim teorijskim postulatima (Gavrilović-Jovanović, 1989; Madžar, 1990). Naime, rezultati pokazuju da su neke privrede pojačavale investicionu aktivnost nastojeći da kroz rast kapitala kompenziraju nepovoljne uticaje određenih činilaca (pre svega, nisku efikasnost). Međutim, efekti pojačane investicione aktivnosti, $\mathrm{u}$ nastojanju da se rastom kapitala kompenzira nepovoljno delovanje drugih činilaca (niske efikasnosti), ograničenog su dejstva i relativno brzo se iscrpljuju.

Pojačavanje investicione aktivnosti $u$ nastojanju da se posredstvom rasta kapitala kompenzira deprimirajuće delovanje ostalih nepovoljnih činilaca, ograničenog je dometa i relativno brzo se iscrpljuje. Iskustvo pokazuje da je, u privredama koje su sledile strategiju ekstenzivnog rasta, prosečni kapitalni koeficijent rastao (Chan, Karceski \& Lakonishok, 2002). Zato je granični kapitalni koeficijent bio veći od prosečnog, a stopa rasta kapitala $\left(\mathrm{r}_{\mathrm{K}}\right)$ veća od stope rasta društvenog proizvoda $\left(\mathrm{r}_{\gamma}\right)$. Zbog toga se smanjuje stopa rasta kapitala $\left(r_{\mathrm{K}}\right)$, a opadanje stope rasta kapitala vrši pritisak nadole na stopu $r_{r}$. Lako se dokazuje da povećanje stope investicija, kada pređe određenu granicu, umesto povećanja dovodi do smanjenja stope rasta: $r\left(r_{Y}\right)=r_{S}-r_{K}$. Kada $k$ počne da raste brže od $s$, stopa rasta $r_{Y}$ počinje da se smanjuje, zbog samog nastojanja da se poveća investicioni napor.

Naime, porast prosečnog kapitalnog koeficijenta $(\bar{k})$ implicira $r_{K}>r_{Y}$ Pošto je $r\left(r_{K}\right)=r_{s}+r_{Y}-r_{K}$ i pošto je $r_{s^{\prime}}$ po pravilu, jednako nuli, a sa nulom se izjednačava ukoliko se u cilju ublažavanja usporavanja rasta pristupi strategiji povećanja stope akumulacije, to podrazumeva da je $r\left(r_{K}\right)<0$, tj. stopa rasta kapitala $\left(\mathrm{r}_{\mathrm{K}}\right)$ se smanjuje. Brzina smanjivanja zavisi od toga da li se sužava jaz između $\overline{\mathrm{k}} \mathrm{i} \mathrm{k}$. Upravo to je razlog što se smanjuje stopa rasta kapitala. Opadanje $r_{K}$ vrši pritisak na snižavanje stope rasta $r_{\gamma}$ Odnosno, sve dok prosečni kapitalni koeficijent $(\overline{\mathrm{k}})$ raste, granični je veći od prosečnog, pa i on, pre ili kasnije, mora da raste, što implicira uticaj u pravcu smanjenja stope $r_{\gamma}$.

Tipična reakcija nekih privreda bila je da se smanjivanje efikasnosti, ispoljeno kroz porast prosečnog kapitalnog koeficijenta, kompenzira povećanjem stope akumulacije (Ristić i Tanasković, 2013 , 88). To može privremeno da odgodi i delimično ublaži posmatrani efekat, ali ne može da ga spreči sve dok se pogoršava odnos između društvenog proizvoda i kapitala ( $\mathrm{Y} / \mathrm{K}$ - produktivnost ili efikasnost kapitala), čime je dokazana hipoteza H2. Određene intervencije mogu ublažiti, ali ne i preokrenuti fundamentalne i egzogeno određene trendove. Stoga se može zaključiti da je reč o mehanizmima koji ne mogu dovesti do trajnog povećanja efikasnosti privređivanja.

Konvergencija stopa $r_{K} i r_{Y}$ može se ostvariti na mnogo različitih načina. Može se ostvariti kroz visoke ili niske stope rasta, zatim, sistem se može brzo spustiti na niske ravnotežne stope, ili da im se približava polako i postepeno (Lawrence \& Williamson, 2014, 215). Ako je na dugi rok neminovan pad stope rasta kapitala, kao posledica opadajuće i niske efikasnosti (tehničkog progresa), na kratak rok postoji i dodatni mehanizam u kome uzročna veza ide u suprotnom smeru. Usporavanje rasta kapitala podrazumeva i manje šanse za tehnički progres. Odnosno, dugoročno usporavanje rasta kapitala, uslovljeno nezadovoljavajućim tehničkim progresom (efikasnošću), sadrži kratkoročnu povratnu spregu u kojoj usporavanje rasta kapitala nepovoljno utiče na stopu tehničkog progresa. 
Pitanje efikasnosti se svodi na delotvornost kojom se upotrebljava raspoloživi privredni potencijal. Strategija forsiranog povećanja količina ne može trajno zameniti nedostatak motivacije, kreativnosti i na njima zasnovanog porasta efikasnosti privređivanja. Čak ni uz stagnantnu efikasnost nije moguće održati poželjni i za tržišne privrede uobičajeni tempo rasta.

Međutim, savršena mera efikasnosti ne postoji, a standardne i najčešće korišćene metode merenja efikasnosti sadrže nemalobrojna i nezanemariva analitička ograničenja. Na primer, prirodna bogatstva, zbog svoje raznolikosti koja se može okarakterisati kao nemerljivost, najčešće se izostavljaju. Zatim, uticaj stranih sredstava se, uglavnom, ne uzima u punoj meri u obzir. Efekti korišćenja dodatnog kapitala priteklog sa strane dolazi do izražaja samo u meri u kojoj se iskazuju kroz uvećanu vrednost proizvodnih fondova, ali njihov uticaj na opšte povećanje efikasnosti, uglavnom, ostaje izvan obuhvata pokazatelja efikasnosti.

\section{ZAKLJUČAK}

Privredni razvoj u svoj njegovoj složenosti nije moguće razumeti ako se ne sagledaju i uvaže vrlo značajni uticaji raznih egzogenih okolnosti koje, po pravilu, deluju i na stopu rasta. Ukazivanje na ovaj složeni mehanizam međuzavisnosti smatramo osnovnim doprinosom ovog rada. Čini se da je sasvim jasno da je navedena relevantna argumentacija da stope rasta, bez obzira kakve su, ne odražavaju razvojne napore niti efikasnost privredno-sistemskih rešenja u intervalima u kojima su zabeležene. „Stopa rasta je potreban, ali ne i dovoljan indikator privrednog rasta" (GavrilovićJovanović, 1989, 65). Tempo rasta se može bitno povećati na uštrb njegovog kvaliteta. Nekvalitetan rast, pre ili kasnije, izaziva usporavanje privredne dinamike, što dokazuje da je privremeno ubrzanje postignuto na račun buduće i dugoročne stope rasta. Pored toga, ukazali smo da strategija ekstenzivnog rasta sadrži činioce koji neminovno produkuju njegovo usporavanje, jer se bazira na mehanizmima koji ne mogu osigurati trajno povećavanje efikasnosti privređivanja. Čak ni intenziviranje investiranja ne može stopu rasta održati na poželjnom i neophodnom nivou. To znači da deceleracija rasta nije slučajnost, već je zakonita posledica suštinske logike funkcionisanja takvog sistema.

Smatramo da je spoznaja složenog mehanizma međuzavisnosti stopa rasta posebno korisna nosiocima mera ekonomske politike, kao i kreatorima razvojnih strategija. Upravo oni moraju imati $u$ vidu da visoke stope rasta $u$ tekućem periodu mogu predstavljati razmenu budućnosti za sadašnjost, ali pod nepovoljnim okolnostima kada se zarad tekućeg žrtvuje budući rast. Naime, bez porasta kvaliteta rasta (efikasnosti) ceo razvojni proces je osuđen na deceleraciju i dugoročnu stagnaciju, a samo rastuća efikasnost omogućava da se na dugi rok u potrebnoj meri valorizuje investiciona aktivnost, kao tradicionalno obilni izvor rasta.

Međutim, mera i pokazatelji kvaliteta rasta, $\mathrm{u}$ teorijsko-metodološkom smislu, nisu jasno definisani, što predstavlja ključno ograničenje ovog rada, ali i relevantno pitanje budućih istraživanja. Područje efikasnosti je ogromno i nepregledno $u$ doslovnom smislu. Stoga, ovde nema, niti može biti, pretenzija da se ono iscrpi, čak ni na nivou najopštijih komponenata, ali je kvalitet rasta i efikasnost ključna smernica daljih istraživanja privrednog rasta. Insistiranje na kvalitativnom aspektu rasta, naravno, nema za cilj da dovede $u$ pitanje veliki značaj visokih stopa rasta, posebno u privredama koje su na nižem nivou razvijenosti. Prvi zadatak kvantitativne analize izvora rasta upravo je identifikovanje faktora od kojih zavisi tempo uvećanja proizvodnje. Pored toga, treba uočiti da je zanemarivanje kvaliteta rasta direktno povezano i sa troškovima. Naime, pored teško merljivog obaranja društvenog blagostanja, lošiji kvalitet rasta znači i veće tekuće izdatke i druge oblike troškova.

Osnovni doprinos ovog rada upravo je identifikovanje fenomena vremenske međuzavisnosti stopa rasta ostvarenih $\mathrm{u}$ sukcesivnim intervalima posmatranog razdoblja, kao gotovo univerzalanog sistema međuzavisnosti. Međutim, isti mehanizam međuzavisnosti je vrlo složen $u$ svom delovanju, pa se $u$ različitim situacijama može govoriti o različitim mehanizmima. Generalno, uspešnost privrednog rasta u bilo kom periodu se, po pravilu, ne može meriti stopom rasta postignutom samo $u$ tom periodu. Zbog vremenske međuzavisnosti u serijama stopa 
rasta, bilo koja konkretno posmatrana stopa odražava $\mathrm{i}$ relevantne karakteristike razvojnih procesa $\mathrm{u}$ prošlosti, ali odražava se i na razvojne uslove i šanse dostizanja zadovoljavajućeg tempa rasta u budućnosti. Postoji nekoliko izvora i rezervi rasta koje mogu biti iscrpljene $\mathrm{u}$ datom periodu, na račun (ili $\mathrm{u}$ prilog) razvojnog potencijala koji ostaje na raspolaganju za buduće periode.

\section{REFERENCE}

Chan, L. K. C., Karceski, J., \& Lakonishok, J. (2002). The Level and Persistence of Growth Rates. The University of Illinois, Washington University and the Western Finance Association.

Denison, E. F. (1984). Accounting for Slower Economic Growth. Washington, USA: The Brookings Institution.

Denison, E. F., \& Poullier, J. (1967). Why the Growth Rates Differ. Washington, USA: The Brookings Institution.

Denison, E. F., Jorgenson, D. W., \& Grilichers, Z. (1972). The Measurement of Productivity. Washington, USA: The Brookings Institution.

Gavrilović-Jovanović, B. (1989). Kvalitet privrednog rasta. Beograd, Srbija: Savremena administracija.

Gligorić, M. (2013, decembar). Priliv stranih direktnih investicija u Srbiju: Novi izazovi u periodu krize. Rad prezentiran na konferenciji: Ekonomske politike Srbije u 2014: Mogućnosti privrednog rasta u uslovima reformi i fiskalne konsolidacije, Ekonomski fakultet Univerziteta u Beogradu, Beograd, Srbija.

Hansen, L., \& Hodrick, R. (1980). Forward exchange rates as optimal predictors of future spot rates: An econometric analysis. The Journal of Political Economy, 88(5), 829-853.

Komazec, S., i Ristić, Ž. (2009). Ekonomija kapitala i finansiranje razvoja. Beograd, Srbija: EtnoStil.

Komazec, S., i Ristić, Ž. (2011). Makroekonimija - makroekonomske teorije i makroekonomska analiza. Beograd, Srbija: EtnoStil.

Lawrence, H. O., \& Williamson, S. H. (2014). Annualized Growth Rate of Various Historical Economic Series. MeasuringWorth

Madžar, Lj. (1990). Suton socijalističkih privreda. Beograd, Srbija: Ekonomika i Institut ekonomskih nauka.

Madžar, Lj. (1981). Međuzavisnost i uporedivost stopa rasta u raznim periodima. Ekonomska misao, 14(3).

Mawson, (2002). Measuring Economic Growth in New Zealand. New Zealand Treasury Working Paper 02/14.

Petrović, P., Bajec, J., Živković, B., Arandarenko, M., Arsić, M. i drugi (2010). Postkrizni model ekonomskog rasta i razvoja Srbije 2011-2020. Beograd, Srbija: Fond za razvoj ekonomske nauke, Ekonomski fakultet Univerziteta u Beogradu.

Publishing OECD (2012). Economic Policy Reforms: Going for Growth.

Republički zavod za statistiku (2013). Aktuelni pokazatelji rasta. Beograd, Srbija.

Rikalović, G. (2010). Razvojna i ekonomska politika i kreativni kapital. Škola biznisa, 7(2), 26-32.

Ristić, B., i Tanasković, S. (2013, decembar). Strategija za unapređenje konkurentske pozicije Srbije prema kompozitnim merilima - primer indeksa globalne konkurentnosti. Rad prezentiran na konferenciji: Ekonomske politike Srbije $\mathrm{u}$ 2014: Mogućnosti privrednog rasta u uslovima reformi i fiskalne konsolidacije, Ekonomski fakultet Univerziteta $\mathrm{u}$ Beogradu, Beograd, Srbija.

Average Annual Growth Rate(AAGR): www.investinganswers. com/financial-dictionary/investing/average-annualgrowth-rate-aagr-2549

Definition of Economic Growth Rate www.investopedia.com/ terms/e/economicgrowthrate.asp

Growth Rates and Terminal Value: people.stern.nyu.edu/ adamodar/pdfiles/ovhds/dam2ed/growthandtermvalue.pdf

Relative Rates of Growth: www.math.psu.edu/files/141rates1. pdf 
Nada Trivić je redovni profesor na Ekonomskom fakultetu u Subotici, Univerzitet u Novom Sadu, na nastavnim predmetima: Mikroekonomija i Mikroekonomski modeli. Autor je i koautor više udžbenika i naučnih monografija, i desetina radova publikovanih u časopisima i radova prezentiranih na međunarodnim i nacionalnim konferencijama.

Viktorija Petrov je asistent na Ekonomskom fakultetu u Subotici, Univerzitet u Novom Sadu, na nastavnim predmetima: Mikroekonomija i Mikroekonomski modeli. Student je doktorskih akademskih studija, na Ekonomskom fakultetu Univeziteta u Beogradu.

\title{
DETERMINATION OF THE ECONOMIC GROWTH RATES BY THE GROWTH QUALITY
}

\author{
Nada Trivic, Viktorija Petrov \\ Faculty of Economics in Subotica, University of Novi Sad, Subotica, Serbia
}

Each specific economic growth rate indicates relevant characteristics of current development, but also reflects the chances for achieving satisfactory future growth rate. Therefore, it is about a general interdependence and law of growth rate convergence. The main objective of this paper is to show that substandard growth could, sooner or later, result in the economic slowdown, and that the temporary growth acceleration can be achieved at the expense of the long-term growth rate. Scientific instruments applicable for achieving this research goal are the method of scientific analysis, historical method and the method of comparative analysis, as well as a number of techniques in the form of modern information resources. A key result of this paper is that all growth rates of endogenous production factors, without increasing the efficiency of resource use, are converging to the arithmetic mean of exogenous production factors growth rates. Therefore, the growth rate can be significantly increased at the expense of its quality and the substandard growth contains the "germs of its own limiting".

Keywords: growth rate, convergence, efficiency, growth quality, growth rates interdependence 